\title{
The Metabolism of Cyclohexanecarboxylate in the Rat
}

\author{
By DAVID BREWSTER,* ROBIN S. JONES and DENNIS V. PARKE \\ Department of Biochemistry, University of Surrey, Guildford, Surrey GU2 $5 X H$, U.K.
}

(Received 26 January 1977)

\begin{abstract}
In the rat, cyclohexanecarboxylate was metabolized and excreted (mostly in the urine) as hippurate, hexahydrohippurate, 3,4,5,6-tetrahydrohippurate and benzoyl and cyclohexylcarbonyl $\beta$-glucuronides. The pattern of metabolism is dose-dependent. With decreasing dose a progressive increase in the conversion into hippurate occurred. This was largely at the expense of glucuronide formation, although the proportions of hexahydro- and tetrahydro-hippurate were also decreased. The observed formation of hexahydrohippurate and 3,4,5,6-tetrahydrohippurate substantiates the proposed mechanism of aromatization of cyclohexanecarboxylate. It appears that these compounds arise via glycine conjugation of active intermediates in the aromatization process. Hexahydrohippurate and 3,4,5,6-tetrahydrohippurate may occur in the urine of rats as new metabolites of shikimate, dependent for their formation on microbial metabolism.
\end{abstract}

Shikimic acid, a naturally occurring acid widespread in plants and certain fruits (Bohm, 1965), has attracted new attention (Stavric \& Stoltz, 1976; Brewster $e$ al., 1976) since the report that the acid may possess carcinogenic properties (Evans \& Osman, 1974). Introductory investigations into the metabolism of this compound have shown that gastrointestinal micro-organisms present in a variety of animal species both hydrogenate and dehydroxylate shikimate to cyclohexanecarboxylate (Brewster et al., 1976, 1977). It has been proposed (Brewster $\boldsymbol{e t}$ al., 1976) that the urinary excretion of hippurate which follows oral administration of shikimate (Asatoor, 1965; Adamson et al., 1970; Brewster et al., 1976) originates from an aromatization of cyclohexanecarboxylate by the mammalian tissues. A complete knowledge of the metabolism of the latter is desirable, therefore, if the ultimate metabolic fate of shikimate is to be understood.

As early as 1911 it was shown that injection of cyclohexanecarboxylate into doge increased the urinary excretion of hippurate (Friedmann, 1911). Subsequent investigations have supported this aromatization and conjugation with glycine (Baltes et al. 1952) and have shown that the process occurs in both liver and kidney (Beer et al., 1951). Experiments in vitro have shown that the liver is the most active tissue for aromatization (Beer et al., 1951) and that the overall enzyme system for this oxidative process is localized in the mitochondria (Mitoma et al., 1958; Babior \& Bloch, 1966). No other metabolites of cyclohexanecarboxylate have as yet been reported.

* Present address: Department of Drug Metabolism, Pharmaceutical Division, Reckitt and Colman, Dansom Lane, Hull HU8 7DS, U.K.

\section{Materials and Methods}

\section{Chemicals}

Cyclohexanecarboxylic acid was obtained from Aldrich Chemical Co., Gillingham, Dorset, U.K., and was distilled twice before use. Benzoic acid and Adam's catalyst (platinum dioxide) were obtained from BDH Chemicals Ltd., Poole, Dorset, U.K., and [ring-U- ${ }^{14} \mathrm{C}$ ]benzoic acid (sp. radioactivity $339 \mathrm{mCi} /$ mmol) from The Radiochemical Centre, Amersham, Bucks., U.K.

\section{Materials}

Cannulae tubing (PP 120, PP 25, PP 10) was obtained from Portex Ltd., Hythe, Kent, U.K. Polystyrene collection tubes (LP 3) were obtained from Luckham Ltd., Burgess Hill, Sussex, U.K., and polypropylene analysis tubes $(0.4 \mathrm{ml}$ capacity) for urine collection from Sarstedt Ltd., Leicester, U.K.

Synthesis of $\left[\right.$ ring- $\left.U-{ }^{14} C\right]$ cyclohexanecarboxylic acid

Cyclohexanecarboxylic acid was prepared by the catalytic hydrogenation of [ring-U- $\left.{ }^{14} \cdot \mathrm{C}\right]$ benzoic acid. Resublimed benzoic acid $(200 \mathrm{mg})$ and $\left[\right.$ ring-U $\left.-{ }^{14} \mathrm{C}\right]-$ benzoic acid $(200 \mu \mathrm{Ci})$ in ethanol $(25 \mathrm{ml})$ were hydrogenated in a Baskerville and Lindsey hydrogenator at 8-10 MPa (80-100atm) in the presence of Adam's catalyst $(40 \mathrm{mg})$. After $12 \mathrm{~h}$ the solution was filtered, evaporated at $20^{\circ} \mathrm{C}$ and the product separated from any traces of unchanged benzoic acid by preparative-layer chromatography (see below) by using acetone/light petroleum (b.p. 40$\left.60^{\circ} \mathrm{C}\right)(1: 2, \mathrm{v} / \mathrm{v})$ as developing solvent. After recovery, the [ring-U- $\left.{ }^{14} \mathrm{C}\right]$ cyclohexanecarboxylic acid (120-180mg; sp. radioactivity $0.95 \mu \mathrm{Ci} / \mathrm{mg}$ ) was 
stored as an aqueous solution of the sodium salt at $-40^{\circ} \mathrm{C}$. The purity $(>98 \%)$ and benzoate content $(<0.8 \%)$ of the product were established by isotope dilution.

\author{
Animals \\ Male Wistar albino rats $(220-250 \mathrm{~g})$ were used in all \\ experiments.
}

\begin{abstract}
Animal surgery
Anaesthesia was induced and maintained by intraperitoneal administration of sodium pentobarbital (Nembutal), and the abdominal viscera exposed for surgery through a midline incision. Cannulation of the bile duct was achieved by using polypropylene tubing (Portex PP 25). In turn, each ureter was located, cleared of mesentery and ligated. Both ureters were cannulated (PP 10 tubing) when sufficiently dilated with urine to enable this operation to be carried out, usually within $10 \mathrm{~min}$ of ligation. To permit intraduodenal dosing of animals, a short length of cannula tubing (PP 25) was introduced into the duodenum via a small incision and secured to the wall by a single ligature. All cannulae were exteriorized before suturing. Bile-duct cannulae were $25 \mathrm{~cm}$ in length and ureter cannulae $8-10 \mathrm{~cm}$.
\end{abstract}

\section{Collection of urine and bile}

Bile was collected in weighed polystyrene LP3 tubes and urine in weighed $0.4 \mathrm{ml}$ polypropylene analysis tubes at $30 \mathrm{~min}$ intervals for up to $7 \mathrm{~h}$, after which the animals were killed by an overdose of Nembutal. Samples were stored at $-40^{\circ} \mathrm{C}$ until required for analysis.

\section{Administration of dose}

$\left[{ }^{14} \mathrm{C}\right]$ Cyclohexanecarboxylic acid $(5-6 \mu \mathrm{Ci}, 0.5-$ $200 \mathrm{mg} / \mathrm{kg}$ ) was administered as the sodium salt in $0.5 \mathrm{ml}$ of water via the duodenal cannula and flushed through with a further $0.25 \mathrm{ml}$ of $0.9 \% \mathrm{NaCl}$. Samples of the dosing solution were taken to determine the precise amount of ${ }^{14} \mathrm{C}$ administered.

\section{Measurement of radioactivity}

Urine $(5 \mu \mathrm{l})$ and bile $(50 \mu \mathrm{l})$ from all $30 \mathrm{~min}$ samples was dissolved in $0.4 \mathrm{ml}$ of water and $4 \mathrm{ml}$ of a Synperonic NXP (I.C.I., Billingham, Teesside, U.K.)/ toluene/2,5-diphenyloxazole scintillant by the method of Wood et al. (1975). Radioactivity was measured in an LKB 1210 liquid-scintillation counter, and the excretion of radioactivity in the urine and bile was calculated as a percentage of the administered dose. Counting efficiencies were obtained by internal standardization by using either $\left[{ }^{14} \mathrm{C}\right]$ toluene or $\left[{ }^{14} \mathrm{C}\right]$ hexadecane.

\section{Solvent extraction of urine and bile}

Radioactive samples of urine and bile were separately combined, diluted with an equal volume of water and acidified to $\mathrm{pH} 1$ with $5 \mathrm{M}-\mathrm{HCl}$. The solutions $(2-3 \mathrm{ml})$ were extracted with five $6 \mathrm{ml}$ portions of ethyl acetate in small $(10 \mathrm{ml})$ screw-capped glass tubes and the layers separated by centrifugation (2000 $\mathrm{g}$ for $30 \mathrm{~s}$ ). Extracts were combined, evaporated, and dissolved in methanol (100-200 $\mu$ l) for examination by t.l.c.

\section{Chromatography}

T.l.c. was carried out on $0.25 \mathrm{~mm}$-thick plates of silica gel $\mathrm{GF}_{254}$ (Anderman and Co., East Molesey, Surrey, U.K.) and preparative-layer chromatography on silica-gel $60 \mathrm{~F}_{254}$ plates of $2 \mathrm{~mm}$ thickness (E. Merck, Darmstadt, Germany). The following solvent systems were used: (a) acetone/light petroleum (b.p. $\left.40-60^{\circ} \mathrm{C}\right) /$ acetic acid $(20: 40: 1$, by vol.); (b) propan-1-ol/ $\mathrm{NH}_{3}$ solution (sp.gr. 0.88$)(7: 3, \mathrm{v} / \mathrm{v})$; (c) butan-1-ol/acetic acid/water (4:1:1, by vol.). All solvents used in the purification of metabolites for either mass spectrometry or p.m.r. (proton-magnetic resonance) spectrometry were of AnalaR quality. System (a) separated all metabolites observed; systems $(b)$ and $(c)$ were used as means of further purification of the metabolites from endogenous impurities. Carboxylic acids were detected by spraying the dried plates with $0.04 \%$ Bromocresol Green in ethanol (Lugg \& Overall, 1948) and glucuronic acid conjugates with $1 \%(\mathrm{w} / \mathrm{v})$ naphtharesorcinol in acetone $/ 10 \%(\mathrm{v} / \mathrm{v})$ phosphoric acid $(4: 1, \mathrm{v} / \mathrm{v})$ followed by heating at $100^{\circ} \mathrm{C}$ for $10 \mathrm{~min}$ (Bridges et al., 1965).

Radioautographs of thin-layer chromatograms were produced on medical X-ray films (BB 54; $18 \mathrm{~cm} \times 24 \mathrm{~cm}$; Kodak, Hemel Hempstead, Herts., U.K.) by contact exposure.

\section{Mass spectrometry}

Electron-impact mass spectra were recorded on an AEI MS12 mass spectrometer equipped with temperature-programming facility. Spectra were run at $70 \mathrm{eV}$ by using direct sample insertion. Urine or bile extracts were applied to t.l.c. plates as $1-2 \mathrm{~cm}$ bands and developed in solvent system (a). For the identification of metabolites 1-3 (see Plate 1) the plates were then sprayed with aq. $7 \mathrm{M}-\mathrm{NH}_{3}$; the metabolites were located by radioautography, then eluted with methanol and rechromatographed separately in solvent sytem $(b)$. Radioactive zones were eluted with methanol (AnalaR grade) by the technique described by Rix et al. (1969), and the final eluates transferred to small, washed melting-point tubes. The methanol was evaporated by a stream of $\mathrm{N}_{2}$ from a finely drawn capillary and the tubes were used as sample probes for direct-insertion mass spectrometry. For the identification of metabolites 4 and 5 , urine or bile extracts were applied as $10 \mathrm{~cm}$ bands to t.l.c. plates and developed in solvent system $(a)$. The compounds were located, then eluted as described above and 
chromatographed as short $(2 \mathrm{~cm})$ bands in solvent system (c). Radioactive zones were removed and eluted with methanol into small conical glass vials (conveniently prepared from the conical section of a Pasteur pipette). The methanolic solutions were first treated with excess of ethereal diazomethane (Vogel, 1956), evaporated by a stream of $\mathrm{N}_{2}$ and left overnight with acetic anhydride (AnalaR grade, $15 \mu \mathrm{l})$ and redistilled pyridine $(15 \mu \mathrm{l})$. Excess of reagents was removed under high vacuum and the resulting triacetylmethyl glucuronates were prepared for direct-insertion mass spectrometry as described above.

\section{P.m.r. spectrometry}

P.m.r. spectra were recorded on a $90 \mathrm{MHz}$ Bruker WH-90 Fourier-transform n.m.r. spectrometer operating at ambient temperature. $\left[{ }^{2} \mathrm{H}_{6}\right]$ Dimethyl sulphoxide was used as solvent and tetramethylsilane as internal standard. Chemical shifts $(\delta)$ are expressed in p.p.m. downfield from tetramethylsilane. For the purification of metabolites 1 and 2, the urine of three animals which had received $\left[{ }^{14} \mathrm{C}\right]$ cyclohexanecarboxylate $(200 \mathrm{mg} / \mathrm{kg})$ was combined and extracted as described above. The extracts were chromatographed on preparative-layer ( $2 \mathrm{~mm}$ thick) silica plates in solvent system $(a)$, the metabolites located and eluted with methanol, then further purified in sequential fashion on t.l.c. plates by using solvent system $(a)$, then system $(b)$. The metabolites were recovered as free acids by elution with methanol, evaporation, acidification with $0.1 \mathrm{M}-\mathrm{HCl}(1 \mathrm{ml})$ and finally extraction into ethyl acetate $(5 \times 5 \mathrm{ml})$.

\section{Quantitative determination of metabolites in urine}

Metabolites in urine were separated by t.l.c. of urine extracts by using solvent system $(a)$ and were located by radioautography. Radioactive zones (see Plate 1) were removed and the powdered silica was suspended in $4 \mathrm{ml}$ of the scintillant described above to which $4 \%(\mathrm{w} / \mathrm{v})$ thixotropic gel (Packard Instruments, Caversham, Berks., U.K.) had been added. Radioactive metabolites were determined as a percentage of the total radioactivity recovered from the plates and converted into percentage of administered dose by reference to the degree of biliary excretion at that dosage. All determinations were carried out in triplicate (which were to within $5 \%$ of each other) and the means obtained.

\section{Results}

After intraduodenal administration of $\left[{ }^{14} \mathrm{C}\right]$ cyclohexanecarboxylate, radioactivity was rapidly eliminated in the urine and bile. Extraction with ethyl acetate at $\mathrm{pH} 1$ removed $97-98 \%$ of the radioactivity present in the urine and $91-92 \%$ of that in the bile. The values were taken as representing complete extraction, since the non-extractable radio- activity represented no more than $2-3 \%$ of the administered dose.

\section{Urinary and biliary excretion of radioactivity}

Intraduodenal administration of $\left[{ }^{14} \mathrm{C}\right]$ cyclohexanecarboxylate at a dosage of $200 \mathrm{mg} / \mathrm{kg}$ led to the ready elimination of radioactivity in both urine and the bile (Fig. 1). At lower dosages the rate of elimination of the dose was very rapid indeed (see Fig. 1). Not only does the rate of excretion increase with decreasing dose, but the extent of biliary excretion is lowered. At the lowest dose studied $(0.5 \mathrm{mg} / \mathrm{kg})$ about $95 \%$ of the administered dose was excreted within the first $90 \mathrm{~min}$.

\section{Metabolites of cyclohexanecarboxylate}

Examination of the ethyl acetate extracts of urine and bile from animals which received $\left[{ }^{14} \mathrm{C}\right]$ cyclohexanecarboxylate $(200 \mathrm{mg} / \mathrm{kg})$ showed the presence of five different metabolites (see Plate 1). The

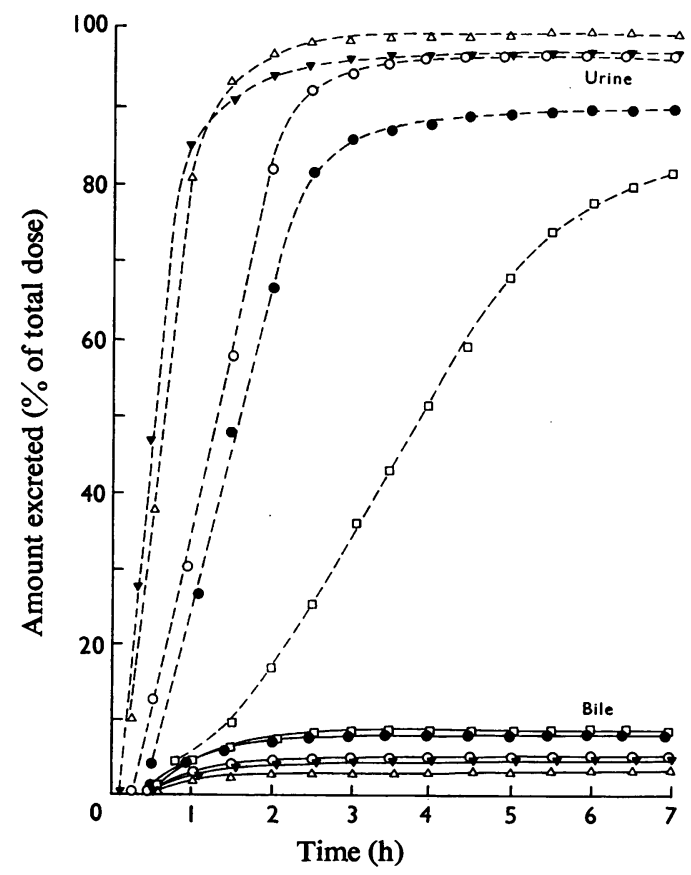

Fig. 1. Effect of dose on the urinary and biliary excretion of radioactivity after intraduodenal administration of $\left[{ }^{14} \mathrm{C}\right]$ cyclohexanecarboxylate to rats

Cyclohexanecarboxylate $(5-6 \mu \mathrm{Ci})$ was administered as the sodium salt in $0.5 \mathrm{ml}$ of water: $\square, 200 \mathrm{mg} /$ $\mathrm{kg} ; \bullet, 100 \mathrm{mg} / \mathrm{kg} ; \bigcirc, 35 \mathrm{mg} / \mathrm{kg} ; \nabla, 5 \mathrm{mg} / \mathrm{kg} ; \triangle, 0.5 \mathrm{mg} /$ kg. Broken lines represent urinary excretion, solid lines represent biliary excretion. Mean flow rates were respectively: urine, $280,210,250,140,170 \mu \mathrm{l} / \mathrm{h}$; bile, $1.22,1.00,0.80,1.20,0.82 \mathrm{ml} / \mathrm{h}$. 
Table 1. Electron-impact mass spectra (70 eV) of cyclohexanecarboxylate and its metabolites in the rat Mass/charge ratios $(\mathrm{m} / \mathrm{e})$ of the six predominant ions are given and their relative abundances included in parentheses.

Compound

Hexahydrohippurate

3,4,5,6-Tetrahydrohippurate

Hippurate

Cyclohexylcarbonyl glucuronide $\dagger$

Benzoyl glucuronide $\dagger$

Cyclohexanecarboxylate
Mol.wt.

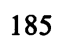

183

179

444

438

128

\begin{tabular}{rrrrrr}
\hline $55(100)$ & $83(71)$ & $41(59)$ & $130(22)$ & $111(15)$ & $* 185(13)$ \\
$109(100)$ & $108(95)$ & $81(79)$ & $79(41)$ & $57(27)$ & $* 183(10)$ \\
$105(100)$ & $77(87)$ & $135(33)$ & $106(25)$ & $134(16)$ & $* 179(2)$ \\
$83(100)$ & $43(93)$ & $111(90)$ & $55(23)$ & $155(18)$ & $* 444(1)$ \\
$105(100)$ & $43(78)$ & $60(27)$ & $77(15)$ & $106(8)$ & $* 438(3)$ \\
$73(100)$ & $55(88)$ & $41(75)$ & $83(61)$ & $* 128(60)$ & $56(60)$
\end{tabular}

* Ions of highest $m / e$ in the spectra $\left(M^{+}\right)$.

$\dagger$ Determined as their triacetylmethyl esters.

Table 2.P.m.r. data of metabolites of cyclohexanecarboxylate in the rat

Spectra were recorded in $\left[{ }^{2} \mathrm{H}_{6}\right]$ dimethyl sulphoxide with tetramethylsilane as internal standard. Chemical shifts $(\delta)$ are in p.p.m. downfield from tetramethylsilane. Abberviations: (d) doublet; (t) triplet; (b) broadened.

\begin{tabular}{|c|c|c|c|c|c|c|}
\hline & $\mathbf{H}_{8}$ & $\mathbf{H}_{7}$ & $\mathbf{H}_{1}$ & $\mathrm{H}_{2}$ & $\mathrm{H}_{3}, \mathrm{H}_{6}$ & $\mathrm{H}_{4}, \mathrm{H}_{5}$ \\
\hline Hexahydrohippurate (I) & 3.69 (d) & $7.96(t)$ & $2.10(\mathrm{~b})$ & $\longrightarrow$ & $1.1-1.8(b$ & - \\
\hline 3,4,5,6-Tetrahydrohippurate (II) & $\begin{array}{c}J_{7,8} 6 \mathrm{~Hz} \\
3.74(\mathrm{~d}) \\
J_{7,8} 6 \mathrm{~Hz}\end{array}$ & $\begin{array}{c}J_{7,8} 6 \mathrm{~Hz} \\
7.96(\mathrm{t}) \\
J_{7,8} 6 \mathrm{~Hz}\end{array}$ & 一 & $6.57(b)$ & 2.14 (b) & $1.56(b)$ \\
\hline
\end{tabular}<smiles>O=C(O)CNC(=O)C1CCCCC1</smiles>

(I)

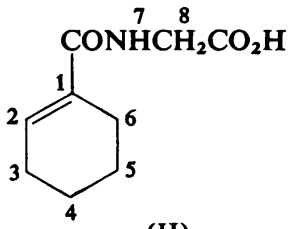

(II)

metabolites, detected by radioautography of thinlayer chromatograms developed in solvent $\operatorname{system}(a)$, were identified by mass spectrometry and p.m.r. as:(1) hexahydrohippurate;(2)3,4,5,6-tetrahydrohippurate; (3) hippurate; (4) cyclohexylcarbonyl $\beta$-D-glucuronide; (5) benzoyl $\beta$-D-glucuronide. The mass spectra of metabolites 1-5 and the p.m.r. spectra of metabolites 1 and 2 are listed in Tables 1 and 2 respectively.

The assignment of structure to the spectra shown was quite straightforward, although the p.m.r. spectrum of metabolite 2 requires further explanation. The mass spectrum $\left(\mathrm{M}^{+}, \mathrm{m} / \mathrm{e} 183\right)$ was consistent with that of an isomeric tetrahydrohippurate, and the presence of a broad olefinic multiplet at $\delta$ 6.57 in the p.m.r. spectrum supported this. Integration of the olefinic signal showed it to be equivalent to exactly one proton when compared with the twoproton doublet at $\delta 3.74$ of the methylene protons of the glycine moiety. This can only be consistent with the 3,4,5,6-tetrahydrohippurate. The downfield position of the olefinic resonance supported the proposed $\alpha \beta$-unsaturation in the metabolite.

All five metabolites were present in urine extracts and gave acidic reactions with ethanolic Bromocresol Green. Hippurate gave a strong quench and tetrahydrohippurate a weak quench of the fluorescence of short wave $(254 \mathrm{~nm})$ u.v. light. Glucuronic acid conjugates of cyclohexanecarboxylate and benzoate were the major products observed in the bile (see Plate 1) and gave positive colour reactions with the naphtharesorcinol reagent.

Metabolism-cage experiments in which animals received $\left[{ }^{14} \mathrm{C}\right]$ cyclohexanecarboxylate $(100 \mathrm{mg} / \mathrm{kg})$ orally showed a similar metabolic pattern. Almost all $(>98 \%)$ of the administered dose was recovered in the urine, and negligible amounts $(<1 \%)$ were in the faeces and expired air. The metabolic pattern in the urine was qualitatively the same as in biliarycannulation experiments, which suggests that the animal surgery described did not influence the metabolism of cyclohexanecarboxylate to any great extent.

\section{Effect of dose on metabolic profile}

Changes in the metabolic pattern occurred when cyclohexanecarboxylate was administered at different doses ranging from 0.5 to $200 \mathrm{mg} / \mathrm{kg}$ (see Table 3). What is most apparent with decreasing dosage is the decrease in glucuronide conjugates and the increase 


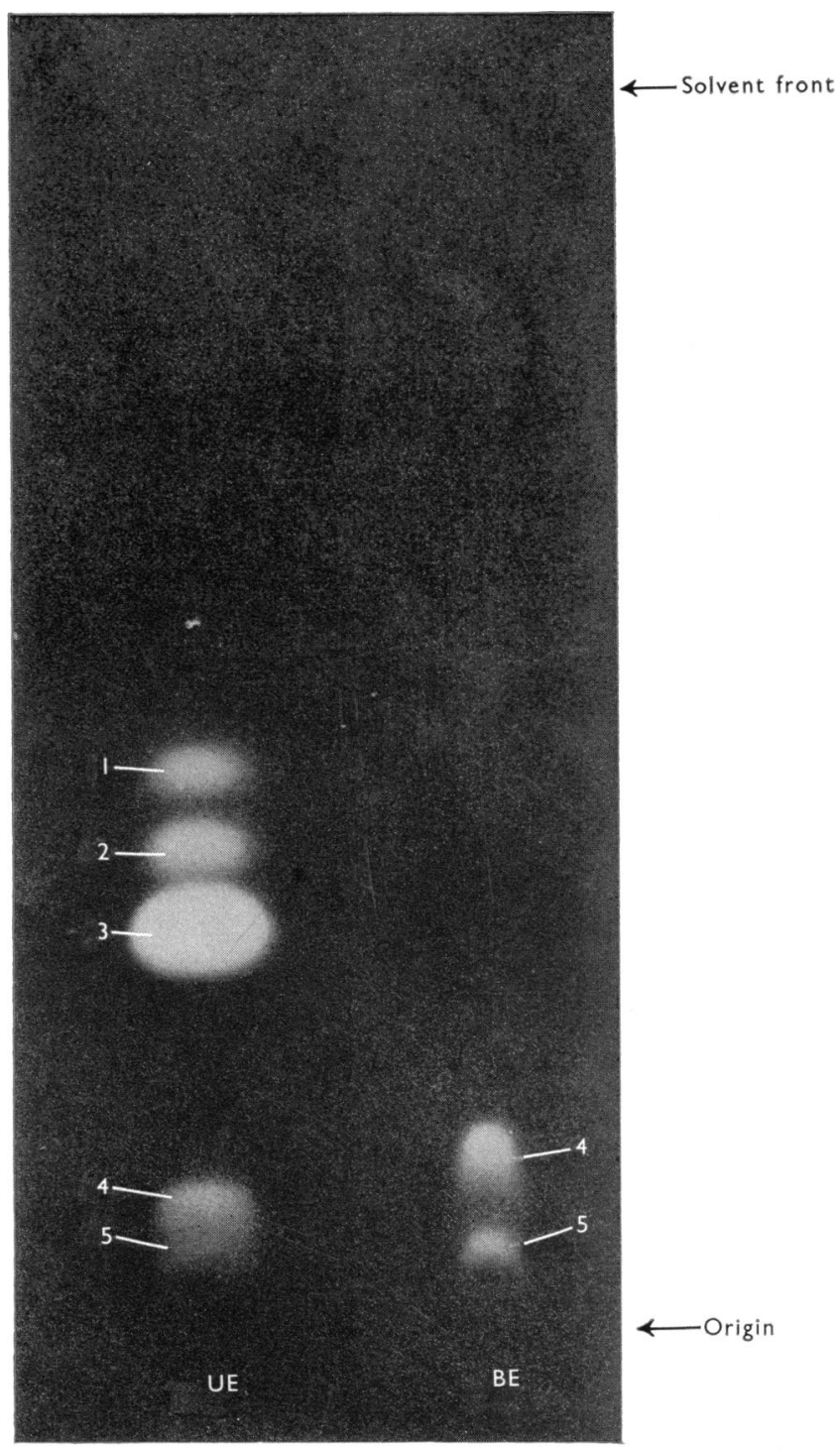

EXPLANATION OF PLATE I

T.l.c. in system (a) of urine extracts $(U E)$ and bile extracts $(B E)$ from rats given $\left[{ }^{14} C\right]$ cyclohexanecarboxylate $\mathrm{X}$-ray film was exposed by direct contact with developed chromatograms and then photographed by contact printing. Key to metabolites: (1) hexahydrohippurate; (2) 3,4,5,6-tetrahydrohippurate; (3) hippurate; (4) cyclohexylcarbonyl $\beta$-D-glucuronide; (5) benzoyl $\beta$-D-glucuronide. 
Table 3. Effect of dose on the metabolism of $\left[{ }^{14} \mathrm{C}\right]$ cyclohexanecarboxylate in the rat Ethyl acetate extracts of urine were subjected to t.l.c. in solvent system (a) and the separated components were then subjected to quantitative radioassay.

Metabolites in urine

\begin{tabular}{|c|c|c|c|c|c|c|}
\hline \multirow[b]{2}{*}{$\begin{array}{c}\text { Dose } \\
(\mathrm{mg} / \mathrm{kg})\end{array}$} & \multirow[b]{2}{*}{$\begin{array}{l}\text { Biliary } \\
\text { excretion } \\
(\% \text { of } \\
\text { dose }) \dagger\end{array}$} & & \multirow[b]{2}{*}{$\begin{array}{c}\text { Total } \\
\text { percentage } \\
\text { of dose } \\
\text { accounted } \\
\text { for }\end{array}$} \\
\hline & & $\begin{array}{l}\text { Benzoyl and } \\
\text { cyclohexyl- } \\
\text { carbonyl } \\
\text { glucuronides } \\
\text { (\% of dose) }\end{array}$ & $\begin{array}{l}\text { Hippurate } \\
\text { ( } \% \text { of dose) }\end{array}$ & $\begin{array}{c}\text { 3,4,5,6-Tetra- } \\
\text { hydro- } \\
\text { hippurate } \\
(\% \text { of dose) }\end{array}$ & $\begin{array}{l}\text { Hexahydro- } \\
\text { hippurate } \\
(\% \text { of dose })\end{array}$ & \\
\hline $\begin{array}{l}200^{*} \\
100\end{array}$ & $8.0 \pm 0.3$ & $18.0 \pm 0.6$ & $48.2 \pm 2.0$ & $12.4 \pm 0.8$ & $10.5 \pm 0.3$ & $97.1 \pm 4.0$ \\
\hline 35 & $\begin{array}{l}7.7 \\
3.9\end{array}$ & $\begin{array}{r}13.6 \\
6.9\end{array}$ & $\begin{array}{l}56.1 \\
70.5\end{array}$ & $\begin{array}{l}9.9 \\
8.6\end{array}$ & $\begin{array}{r}10.0 \\
6.1\end{array}$ & $\begin{array}{l}97.3 \\
96.0\end{array}$ \\
\hline 5 & 3.8 & 2.4 & 75.0 & 9.2 & 6.6 & 97.0 \\
\hline 0.5 & 3.0 & 1.4 & 81.0 & 8.1 & 4.9 & 98.4 \\
\hline
\end{tabular}

* Values at this dosage represent the means for three animals \pm S.E.M.

$\dagger$ Radioactivity in the bile was almost entirely glucuronide conjugates of cyclohexanecarboxylate and benzoate.<smiles>O=C(O)[C@H]1O[C@H](C(=O)O)[C@H](O)[C@@H](O)[C@@H]1O</smiles>

(4)<smiles>C[13CH3]</smiles><smiles>O=C(O)C1CCCCC1</smiles><smiles>O=C(O)OC(=O)C1=CCCCC1</smiles><smiles>O=C(O)CNC(=O)C1CCCCC1</smiles>

(1)<smiles>[13CH3]</smiles>

(b)<smiles>O=C(O)CNC(=O)C1=CCCCC1</smiles>

(2)<smiles>O=C(O[C@H]1[C@@H](O)[C@@H](O)[C@H](O)[C@H]1O)c1ccccc1</smiles>

(5)<smiles></smiles><smiles>CC(=O)OS(=O)(=O)c1ccccc1</smiles>

(c)<smiles>O=C(O)CNC(=O)c1ccccc1</smiles>

(3)

Scheme 1. Metabolism of cyclohexanecarboxylate in the rat

Key to metabolites: (1) hexahydrohippurate; (2) 3,4,5,6-tetrahydrohippurate; (3) hippurate; (4) cyclohexylcarbonyl $\beta$-D-glucuronide; (5) benzoyl $\beta$-D-glucuronide. Pathways indicated* are dose-dependent and are unimportant at low dosages (<1 mg/kg). References: (a) Mitoma et al. (1958); (b) Babior \& Bloch (1966); (c) Schachter \& Taggart (1953).

in hippurate. The fact that glucuronide formation is greatest at the higher dosages seems to account for the fact that biliary excretion, although a minor route of excretion of cyclohexanecarboxylate, is greatest at the higher dosages (see Fig. 1).

\section{Discussion}

In the rat, cyclohexanecarboxylate was metabolized to hippurate, hexahydrohippurate, 3,4,5,6tetrahydrohippurate and benzoyl and cyclohexyl- 
carbonyl glucuronides, of which only hippurate has previously been reported (Friedmann, 1911; Beer et al., 1951; Baltes et al., 1952; Mitoma et al., 1958; Babior \& Bloch, 1966). The metabolism of cyclohexanecarboxylate is dose-dependent, with considerable amounts of benzoyl and cyclohexylcarbonyl glucuronides being formed only at higher dosages. This dose-dependence of cyclohexanecarboxylate metabolism raises important considerations in the metabolism of shikimate, a potential carcinogen (Evans \& Osman, 1974) which is metabolized by rat caecal micro-organisms to cyclohexanecarboxylate (Brewster et al., 1976). Although shikimate itself is poorly absorbed from the gut, it is slowly converted by microbial action into cyclohexanecarboxylate, which is then absorbed and metabolized in the mammalian tissues. The microbial reduction of an oral dose of shikimate to rats yields cyclohexanecarboxylate at a rate of approx. $1-2 \mathrm{mg} / \mathrm{h}$ per $\mathrm{kg}$ body wt. (Brewster, 1977). Clearly the metabolism of cyclohexanecarboxylate at low doses is most relevant to the metabolic fate of shikimate, and hexahydroand 3,4,5,6-tetrahydro-hippurates should occur therefor as metabolites of shikimate in the urine, in addition to hippurate, a known metabolite.

Since shikimate occurs widely in plants and fruits (Bohm, 1965) and is converted into cyclohexanecarboxylate by a variety of animal faecal microflora (Brewster et al., 1977), then hexahydro- and 3,4,5,6tetrahydro-hippurate should occur naturally in the urine of animals as does hippurate. Hexahydrohippurate has been detected in the urine of cattle (Suemitsu et al., 1971) and therefore the microbial conversion of dietary shikimate into cyclohexanecarboxylate followed by metabolism in the animal tissues appears to offer a viable explanation for this observation. This mechanism is an alternative to the pathway suggested by Rho \& Evans (1975), namely that hexahydrohippurate may arise from a microbial reduction of benzoate or hippurate, and is strengthened by the fact that rat gastrointestinal micro-organisms do not appear to reduce benzoate either in vitro or in vivo (Brewster, 1977). The presence of 3,4,5,6-tetrahydrohippurate in animal urine has yet to be reported.

These new metabolites of cyclohexanecarboxylate, namely hexahydro- and 3,4,5,6-tetrahydro-hippurate, provide further information on the mechanism of its aromatization by mammalian tissues to hippurate. The process probably involves dehydrogenation of intermediate $\mathrm{CoA}$ esters before conjugation of benzoyl-CoA with glycine (see Scheme 1). The urinary excretion of hexahydro- and 3,4,5,6-tetrahydro-hippurates substantiates these proposed intermediates.

We thank the Science Research Council for a studentship to D. B. The assistance of Mr. J. S. Delderfield (Department of Chemistry, University of Surrey) in the running of mass spectra is greatly appreciated.

\section{References}

Adamson, R. H., Bridges, J. W., Evans, M. E. \& Williams, R. T. (1970) Biochem. J. 116, 437-443

Asatoor, A. M. (1965) Biochim. Biophys. Acta 100, 290-292

Babior, B. M. \& Bloch, K. (1966) J. Biol. Chem. 24, 3643-3651

Baltes, B. J., Elliott, W. H., Doisy, E. A., Jr. \& Doisy, E. A. (1952) J. Biol. Chem. 194, 627-634

Beer, C. T., Dickens, F. \& Pearson, J. (1951) Biochem. J. 48, 222-237

Bohm, B. A. (1965) Chem. Rev. 65, 435-466

Brewster, D. (1977) Ph.D. Thesis, University of Surrey

Brewster, D., Jones, R. S. \& Parke, D. V. (1976) Biochem. Soc. Trans. 4, 518-521

Brewster, D., Jones, R. S. \& Parke, D. V. (1977) Xenobiotica 7, 109

Bridges, J. W., Kibby, M. R. \& Williams, R. T. (1965) Biochem. J. 96, 829-836

Evans, I. A. \& Osman, M. A. (1974) Nature (London) 250, 348-349

Friedmann, E. (1911) Biochem. Z. 35, 49-56

Lugg, J. H. W. \& Overall, B. T. (1948) Aust. J. Sci. Res. 1, 98-106

Mitoma, C., Posner, H. S. \& Leonard, F. (1958) Biochim. Biophys. Acta 27, 156-160

Rho, E. M. \& Evans, W. C. (1975) Biochem. J. 148, 11-15

Rix, M. J., Webster, B. R. \& Wright, I. C. (1969) Chem. Ind. 452

Schachter, D. \& Taggart, J. V. (1953) J. Biol. Chem. 203, 925-934

Stavric, B. \& Stoltz, D. R. (1976) Food Cosmet. Toxicol. 14, 141-145

Suemitsu, R., Fujita, S. \& Kamata, T. (1971) Agric. Biol. Chem. 35, 132-135

Vogel, A. I. (1956) A Textbook of Practical Organic Chemistry, 3rd edn., pp. 969-973, Longmans, London

Wood, P., English, J., Chakraborty, J. \& Hinton, R. (1975) Lab. Pract, 24, 739-740 